\title{
Representasi verbal siswa sekolah menengah pertama dalam mengkomunikasikan faktor prima
}

\section{Sukiyanto*}

Universitas Sarjanawiyata Tamansiswa, Kota Yogyakarta, Daerah Istimewa Yogyakarta, Indonesia, 55167

\section{Fitry Wahyuni}

Akademi Perniagaan dan Perusahaan APIPSU, Medan, Sumatera Utara, Indonesia, 20123

*Corresponding Author: sukiyanto.math@ustjogja.ac.id

\begin{abstract}
The purpose of this study was to describe students' communication in solving prime factors using written and oral communication. This study uses a qualitative and descriptive approach. The subjects of this study were 46 seventh grade students of Simanjaya Lamongan, East Java, Indonesia, Middle School who had obtained prime factor material. Data analysis was obtained by using a test of prime factors and interviews. Based on the results of data analysis, it was concluded that: 1) Written communication, as many as 40 students were able to communicate in writing with a percentage of $87 \%$ and 6 students were unable to communicate in writing with a percentage of $13 \%$; 2) Oral communication, at this stage interviews were conducted by taking the subject as many as two students taken from one student who is able to communicate in writing and one student who is not able to communicate in writing, the results obtained that students are able to communicate in writing are also able to communicate verbally. verbally, while students who are not able to communicate in writing, it turns out that students are able to communicate orally. From the explanation above, it can be concluded that students are able to explain concepts into mathematical language, students are able to explain mathematical arithmetic operations, students are able to explain mathematical solutions and students are able to convey ideas or opinions. Thus, students can communicate in writing and orally well in solving prime factors.
\end{abstract}

Historis Artikel:

Diterima: 2 Juli 2021

Direvisi: 6 Agustus 2021

Disetujui: 29 Agustus 2021

\section{Keywords:}

Communication; prime

factors; verbal

representation

Sitasi: Sukiyanto, S., \& Wahyuni, F. (2021). Representasi verbal siswa sekolah menengah pertama dalam mengkomunikasikan faktor prima. Journal of Didactic Mathematics, 2(2), 76-86. Doi: 10.34007/jdm.v2i2.846

\section{PENDAHULUAN}

Komunikasi sebagai proses interaksi dalam mengungkapkan ide-ide yang abstrak pada suatu masalah matematika (Rogers \& Rekha, 1979; Shannon \& Weaver, 1949; Severin, 2005) dan dapat diwakilkan dalam representasi (Bartell et al., 2012). Kemampuan komunikasi matematis siswa menjadi bagian dari kemampuan standar bermatematika di sekolah. Pernyataan tersebut merupakan satu di antara standar proses yang ditetapkan oleh The National Council of Teachers of Mathematics (NCTM). Hal tersebut juga sama dengan tujuan dalam pembelajaran matematika pada Peraturan Menteri Pendidikan dan Kebudayaan Nomor 81A (Kemendikbud, 2013) dijelaskan bahwa dalam proses pembelajaran memiliki lima pokok utama yaitu 1) mengamati; 2) menanya; 3) mengumpulkan informasi; 4) mengasosiasi; dan 5) mengomunikasikan.

Selanjutnya tujuan pembelajaran matematika Sekolah Menengah Pertama ada tujuh, 1) memahami konsep Matematika, menjelaskan keterkaitan antar konsep dan mengaplikasikan konsep atau algoritma, secara luwes, akurat, efisien, dan tepat, dalam menyelesaikan masalah matematika; 2) menggunakan penalaran pada pola dan sifat, melakukan manipulasi matematika dalam membuat generalisasi, menyusun bukti, atau menjelaskan gagasan dan pernyataan matematika; 3) menyelesaikan masalah matematika yang meliputi kemampuan memahami 
Representasi verbal siswa sekolah menengah pertama dalam...

masalah, merancang model matematika, menyelesaikan model dan menafsirkan solusi yang diperoleh; 4) mengomunikasikan gagasan dengan simbol, tabel, diagram, atau media lain untuk memperjelas keadaan; 5) menghargai kegunaan matematika dalam kehidupan, yaitu memiliki rasa ingin tahu, perhatian, dan minat dalam mempelajari matematika, serta sikap ulet dan percaya diri dalam menyelesaikan masalah matematika; 6) menalar secara logis dan kritis serta mengembangkan aktivitas kreatif dalam menyelesaikan masalah matematika dan mengkomunikasikan ide; dan 7) memberi kemampuan untuk menerapkan matematika pada setiap bidang (Kemendikbud, 2013).

Kemampuan komunikasi matematis merupakan cara berbagi ide yang lebih mementingkan pada kemampuan dalam berbicara, menulis, menggambar, dan menjelaskan konsep-konsep matematika (van de Walle, et al., 2008). Menurut Baroody (1993) mengomunikasikan matematika perlu ditumbuh kembangkan di kalangan siswa karena mempunyai dua alasan yaitu: 1) mathematics as language artinya matematika tidak hanya sekedar alat bantu berpikir, dan menyelesaikan masalah, tetapi juga sebagai alat untuk mengomunikasikan berbagai ide secara jelas, tepat dan cermat; 2) mathematics learning as social activity; artinya sebagai aktivitas sosial dalam pembelajaran matematika, dan sebagai wahana interaksi antar sosial, dan juga komunikasi antara guru dan siswa. Sejalan dengan pendapat tersebut Ningsih, Narahara, \& Mulyono (2018) mengatakan bahwa siswa dapat mengomunikasi dengan lancar tanpa ada hambatan dipengaruhi oleh faktor kebiasaan dalam proses pembelajaran yang menggunakan diskusi berkelompok. Sedangkan kemampuan mengomunikasikan matematika siswa rendah, disebabkan oleh: 1) guru sering mencontohkan pada siswa bagaimana menyelesaikan soal; 2) siswa belajar dengan cara mendengar dan melihat guru dalam memecahkan masalah matematika, dan 3) guru cenderung lebih suka mengajar dengan cara langsung menjelaskan materi yang dipelajari. Hal tersebut salah satu faktornya yaitu dipengaruhi kurangnya siswa meningkatkan konsep pemahaman suatu permasalahan (Hussien, 2018; Utami at al., 2019). Pada studi pendahuluan yang dilakukan oleh peneliti, menemukan bahwa sebagian siswa mengalami kendala dalam mengomunikasikan faktor prima saat proses pembelajaran berlangsung.

Faktor prima merupakan salah satu mata pelajaran yang sangat penting, tetapi banyak siswa yang mengalami kesulitan dalam memahami dan cara menentukannya. Faktor prima disebut suatu faktor yang hanya terdiri dari bilangan-bilangan prima. Untuk menentukan suatu faktor prima dari suatu bilangan komposit, pertama harus menulis kembali bilangan itu sebagai suatu hasil kali dua bilangan yang lebih kecil. Selanjutnya, pemfaktoran bilangan-bilangan yang lebih kecil sampai seluruh faktornya adalah bilangan prima. Sebagai contoh, Mengomunikasikan faktor prima dari 42. 42 dapat dibagi dengan bilangan prima paling kecil yang bisa dibagi dengan 42 yaitu $2.42 \div 2=21$, selanjutnya 21 dibagi dengan bilangan prima paling kecil yang bisa dibagi dengan 21 yaitu $3.21 \div 3=7$, cukup berhenti di angka 7 karena 7 tidak bisa dibagi lagi dengan bilangan prima. Maka faktor dari 42 adalah $2 \times 3 \times 7$. Metode atau cara pembagian ini, sering digunakan guru dan siswa dalam menentukan suatu nilai faktor prima (Jordan, 2016). Dalam sebuah hasil penelitian rata-rata siswa gagal dalam menentukan faktorisasi prima, mereka tidak menghitungkan setiap bilangan yang dapat mewakili dalam perhitungan dari faktor prima, (Zazkis \& Gadowsky, 2001). Metode atau cara yang kedua, untuk mencari faktor prima dari suatu bilangan juga dapat menggunakan pohon faktor. Pohon faktor merupakan penyelesaian pemecahan pembagian dengan menggunakan cabang pohon atau diagram pohon untuk memfaktorkan suatu bilangan.

Dalam menemukan faktor prima dari suatu bilangan harus memahami konsep dan mengenal teorema dasar aritmatika yaitu setiap bilangan komposit dapat ditulis sebagai hasil kali bilangan-bilangan prima dalam satu cara. Selain meningkatkan pemahaman konsep siswa juga harus dapat memiliki keterampilan berkomunikasi baik secara verbal maupun tertertulis sebagai kesiapan mereka untuk menghadapi kehidupan dimasa depan (Wagner, 2008; Reynolds et al., 2012; Saavedra \& Opfer, 2012) Untuk mengatasi masalah di atas, juga diperlukan pembelajaran yang dapat membuat siswa lebih aktif yaitu melalui pendekatan scientific yang diimplementasikan 
dalam kurikulum 2013. Dalam implementasi kurikulum 2013 pemerintah menempatkan peran guru hanya sebagai fasilitator dalam pembelajaran. Kurikulum 2013 menekankan pembelajaran dengan pendekatan scientific bertujuan agar siswa lebih mampu mengembangkan kemampuan komunikasi matematika. Pendekatan pembelajaran scientific dimulai dari mengamati, menanya, mengumpulkan informasi, menalar, dan komunikasi (Wildan et al., 2019).

Kemampuan siswa dalam berkomunikasi memainkan peran penting dalam menyelesaikan masalah matematika, maka hal ini berdampak positif pada pembelajaran matematika secara mandiri (Yaniawati et al., 2017). Dalam menyelesaikan masalah matematika, siswa juga dituntut untuk menyusun strategi yang tepat dan digunakan dalam menyelesaikan proses permasalahan saat mengalami kesulitan (Sukiyanto, 2020). Sedangkan NCTM (2000) berpendapat bahwa proses pembelajaran matematika adalah untuk memecahkan masalah, penalaran, berkomunikasi dalam matematika, yang seluruhnya berkaitan dengan representasi. Representasi terbagi menjadi tiga, yaitu: 1) representasi verbal, yaitu berupa kata-kata, lisan dan deskripsi; 2) representasi visual, yaitu berupa grafik, animasi, dan video; dan 3) representasi simbolik, yaitu berupa rumus, gambar, skema, diagram dan simbol matematika (Adu-Gyamfi, 2003; Prain, \& Waldrip, 2006; As'ari, 2009; Kohnle \& Passante, 2017). Menurut Baroody (1993), ada lima aspek komunikasi matematis, yaitu merepresentasi (representating), mendengar (listening), membaca (reading), diskusi (discussing), dan menulis (writing). Sedangkan komunikasi matematis dibagi lagi menjadi dua yaitu: 1) komunikasi matematis secara lisan; dan 2) komunikasi matematis secara tertulis. Indikator dalam komunikasi matematis secara lisan, yaitu: 1) siswa dapat menjelaskan konsep kedalam bahasa matematika; 2) siswa dapat menjelaskan masalah kedalam bahasa matematika; 3) siswa dapat menjelaskan operasi perhitungan; 4) siswa dapat menjelaskan solusi matematika; 5) siswa dapat menjelaskan interpretasi jawaban; dan 6) siswa dapat menyampaikan ide atau pendapat. Sedangkan indikator dalam komunikasi matematis secara tertertulis diantaranya yaitu: 1) siswa dapat menuliskan konsep kedalam bahasa matematika; 2) siswa dapat menuliskan masalah kedalam bahasa matematika; 3) siswa dapat menuliskan operasi perhitungan; 4) siswa dapat menuliskan solusi matematika; dan 5) siswa dapat menuliskan kesimpulan jawaban.

Ketika siswa mengomunikasikan matematis juga harus membangun pemahaman konseptual melalui literasi matematika sehingga siswa mampu memecahkan masalah matematika dengan baik. Representasi itu muncul dikarenakan faktor kemampuan siswa dalam literasi matematika (Murat \& Funda, 2016). Representasi merupakan hal yang tidak bisa dipisahkan dalam pembelajaran matematika. Meskipun tidak tercantum secara tersurat dalam tujuan pembelajaran matematika di Indonesia, namun secara tersirat pentingnya representasi tampak pada tujuan pemecahan masalah dan komunikasi matematika, karena untuk menyelesaikan masalah matemati.

Beberapa peneliti terdahulu telah melakukan penelitian untuk melihat bentuk komunikasi representasi yang efektif dalam menyelesaikan masalah matematika (ÇELIK \& Arslan, 2012; Boonen et al., 2014; Dündar, 2015) hasil penelitiannya menjelaskan bahwa bentuk representasi yang sering digunakan siswa saat menyelesaikan masalah matematika adalah berupa representasi verbal dan representasi visual. Rahmad \& Dwi (2017) menjelaskan bahwa siswa menggunakan representasi verbal sebagai proses memahami masalah. Bentuk dari representasi verbal tersebut berupa kalimat tertertulis sehingga masalah dapat diselesaikan dengan benar. Sejalan dengan hasil penelitian Hoogland et al. (2018), mengungkapkan bahwa siswa mampu merepresentasikan dengan baik pada masalah dalam kehidupan sehari-hari yang dikaitkan dengan representasi dunia nyata, maka akan terwujud dalam representasi verbal.

Representasi verbal siswa dalam memecahkan masalah faktor prima merupakan hal yang tidak mudah. Karena sebelum siswa dapat mengomunikasikan tentang faktor prima maka siswa harus mampu menentukan faktor dan bilangan prima (Cooney, 1999). Beberapa penelitian tentang representasi matematis pada materi faktor prima telah dilakukan oleh beberapa peneliti yaitu Burkhart (2009); Arcavi (2003); dan Roscoe \& Feldman (2015). Hasil penelitian Burkhart (2009) mengungkapkan bahwa siswa mampu memahami faktor prima melalui representasi visual 
Representasi verbal siswa sekolah menengah pertama dalam...

yang digambarkan dengan pohon faktor. Arcavi (2003) menjelaskan representasi visual dapat membantu proses berpikir siswa tentang konsep dan makna yang dipahami dan dijelaskan dalam bentuk representasi simbolik. Hasil dari Roscoe \& Feldman (2015) mengungkapkan bahwa guru memberikan pemahaman kepada siswa dalam membedakan antara faktor dan faktorisasi prima menekankan pada langkah-langkah dalam menentukan bilangan tersebut. Beberapa hasil penelitian tersebut yang telah dilakukan oleh peneliti sebelumnya, belum ada yang meneliti tentang representasi verbal siswa secara lisan dan tertulis dalam menyelesaikan faktor prima. Sehingga pada penelitian ini, peneliti ingin mendeskripsikan representasi verbal siswa sekolah menengah pertama dalam mengkomunikasikan faktor prima.

Berdasarkan studi pendahuluan yang telah dilakukan peneliti, diperoleh hasil bahwa siswa mampu menggunkaan representasi verbal dan mengomunikasikannya secara lisan dan tertulis dalam menyelesaikan faktor prima. Peneliti menemukan dua bentuk representasi yang digunakan siswa yaitu secara lisan dan tertulis, secara lisan siswa dapat menuliskan konsep faktor prima kedalam bahasa matematika, siswa dapat menuliskan operasi perhitungan, dan siswa dapat menuliskan solusi matematika yang dibuktikan dengan siswa bisa menyelesaikan faktor prima dengan menggunakan kata-kata, siswa mampu menjelaskan tentang faktor, faktorisasi, dan faktor prima, kemudian siswa juga mampu menjelaskan perbedaaan bilangan prima dan bilangan komposit. Selanjutnya secara tertulis siswa membuktikan bahwa 5 dan 3 adalah faktor prima karena 5 dan 3 merupakan bilangan prima dan mempunyai faktor sebanyak 2 yaitu 1, 5 dan 1, 3 . Sedangkan 9 bukan termasuk faktor prima karena 9 adalah bilangan komposit dan mempunyai faktor 1, 3, 3, dan 9. Oleh karena itu, perlu dilakukan penelitian secara mendalam terkait dengan representasi verbal siswa SMP dalam mengomunikasikan faktor prima.

\section{METODE}

Penelitian ini menggunakan pendekatan kualitatif dan jenis penelitian yang dilakukan bersifat deskriptif. Penelitian kualitatif adalah penelitian yang berupa deskriptif kata-kata dari subjek, menjelaskan dan melakukan analisa secara subjektif (Cresswell, 2009). Pendekatan kualitatif digunakan untuk memperoleh pemahaman siswa secara mendalam dan untuk mengetahui komunikasi siswa yang digunakan dalam menyelesaikan faktor prima.

Subjek dalam penelitian ini yakni siswa kelas VII SMP Simanjaya Lamongan Jawa Timur Indonesia, yang berjumlah 49 siswa. Dari jumlah 49 siswa, yang akan dijadikan subjek penelitian adalah 46 siswa, karena ketika peneliti mengambil data penelitian ada tiga siswa yang tidak masuk sekolah, yaitu dua siswa izin karena sakit, dan satu siswa lagi izin karena ada kegiatan keluarga, sehingga jumlah subjek penelitian adalah berjumlah 46 siswa. Untuk memperoleh data penelitian, peneliti memberikan tes berisi soal uraian faktor prima. Yang bertujuan untuk mengidentifikasi komunikasi siswa dalam menyelesaikan faktor prima. Soal tes yang diberikan pada siswa memodifikasi dari Jordan (2016). Karena dalam penelitian ini juga ingin mengidentifikasi komunikasi siswa dalam menyelesaikan faktor prima.

Metode yang dilakukan dalam pengambilan data dengan menggunakan tes dan wawancara. Tes dilakukan untuk memperoleh data tentang kemampuan siswa dalam berkomunikasi secara lisan, tes dalam penelitian ini disusun dalam bentuk soal uraian pada materi faktor prima sebanyak dua item. Wawancara dilakukan untuk memperolah data siswa dalam berkomunikasi lisan dalam menyelesaikan faktor prima. Wawancara yang dilakukan dalam penelitian adalah wawancara tidak terstruktur. Wawancara tidak terstruktur adalah jenis wawancara dalam kategori in-dept interview, dimana dalam pelaksanaannya lebih bebas bila dibandingkan dengan wawancara terstruktur (Sugiyono, 2012).

Ada dua siswa yang digunakan sebagai subjek wawancara yang masing-masing diambil satu siswa yang mampu berkomunikasi secara tertulis dan satu siswa yang tidak mampu berkomunikasi secara tertulis. Wawancara yang dilakukan oleh peneliti adalah wawancara berbasis jawaban siswa. Data yang diperoleh dari penelitian ini berupa lembar jawaban siswa dan hasil wawancara. Data berupa lembar jawaban siswa selain digunakan untuk mengidentifikasi 
komunikasi secara tertulis juga digunakan untuk menentukan siswa yang akan diwawancarai. Sedangkan data yang diperoleh dari hasil wawancara digunakan untuk mengidentifikasi komunikasi siswa secara lisan dalam menyelesaikan faktor prima.

\section{HASIL DAN PEMBAHASAN}

Peneliti menemukan siswa yang mampu menggunakan representasi verbal dengan mengomunikasikan secara tertulis dalam menyelesaikan faktor prima dengan metode pohon faktor, Siswa yang mampu mengomunikasikan secara tertulis juga mampu secara lisan, sedangkan siswa yang tidak bisa mengomunikasikan secara tertulis namun mampu secara lisan. Data yang diperoleh dari hasil tes berupa lembar jawaban tertulis digunakan untuk mengidentifikasi komunikasi siswa secara tertulis, dan data yang diperoleh dari hasil wawancara yang berupa transkip wawancara dapat digunakan untuk mengidentifikasi komunikasi secara lisan. Hasil komunikasi siswa secara tertertulis sebesar $87 \%$ yaitu 40 siswa, sedangkan siswa yang tidak mampu secara tertertulis sebesar 13\% yaitu 6 siswa

Hasil lembar kerja jawaban siswa yang berkomunikasi secara tertulis dapat dilihat pada Gambar 1.

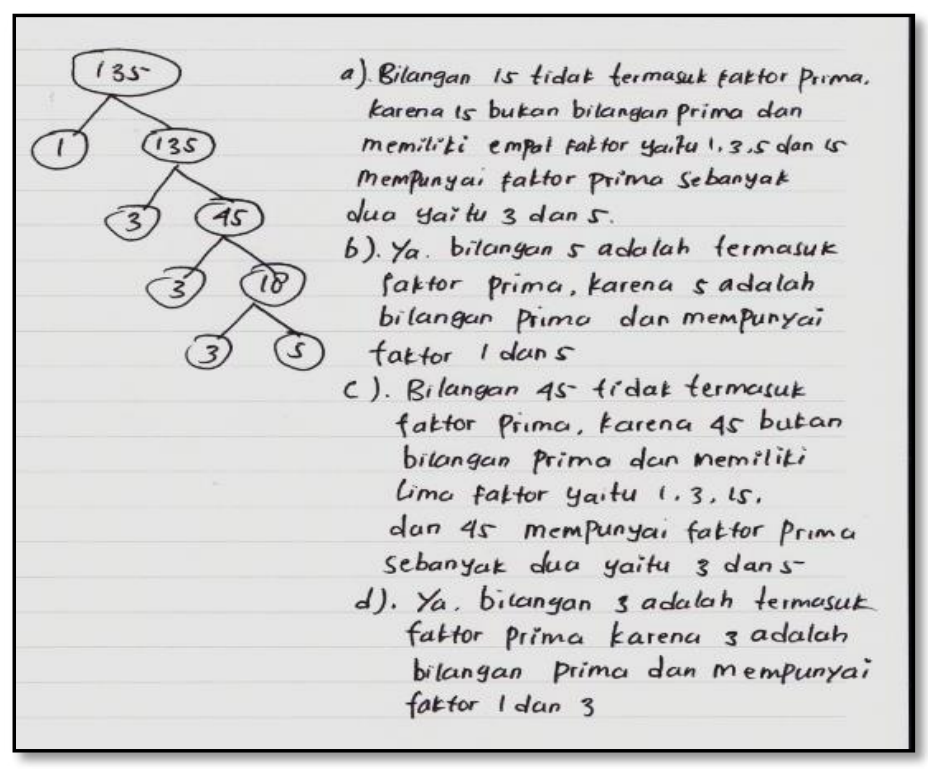

Gambar 1. Siswa yang mampu berkomunikasi secara tertulis.

Dari Gambar 1 diatas peneliti mendeskripsikan jawaban siswa yang mampu berkomunikasi secara tertulis dalam menyelesaikan faktor prima sesuai dengan indikator komunikasi secara tertulis dapat dilihat pada Tabel 1.

Tabel 1. Deskripsi jawaban siswa yang mampu berkomunikasi secara tertulis

\begin{tabular}{|c|c|c|c|}
\hline No & Indikator komunikasi secar & tertulis & Deskripsi jawaban siswa \\
\hline 1 & $\begin{array}{l}\text { Siswa dapat menuliskan } \\
\text { kedalam bahasa matematika }\end{array}$ & konsep & $\begin{array}{l}\text { Siswa dapat membedakan bilangan prima dan } \\
\text { bilangan komposit, bilangan prima adalah } 5 \\
\text { dan } 3 \text {. Sedangkan bilangan komposit adalah } \\
15 \text { dan } 45\end{array}$ \\
\hline 2 & $\begin{array}{l}\text { Siswa dapat menuliskan } \\
\text { kedalam bahasa matematika }\end{array}$ & masalah & $\begin{array}{l}\text { Siswa dapat menjelaskan bahwa bilangan } 5 \\
\text { dan } 3 \text { merupakan faktor prima, karena } \\
\text { bilangan } 5 \text { dan } 3 \text { adalah bilangan prima yang } \\
\text { mempunyai dua faktor. } 5 \text { memiliki faktor } 1 \\
\text { dan } 5 \text { sedangkan } 3 \text { memiliki faktor } 1 \text { dan } 3\end{array}$ \\
\hline 3 & menuliskan & operasi & Siswa dapat menghitung nilai $N=135$ yang \\
\hline
\end{tabular}


Representasi verbal siswa sekolah menengah pertama dalam...

\begin{tabular}{|c|c|c|}
\hline & perhitungan & $\begin{array}{l}\text { diketahui dari } N=3 \times 5 \times 9 \text { kemudian } \\
\text { siswa dapat membagi dengan menggunakan } \\
\text { pohon faktor }\end{array}$ \\
\hline 4 & $\begin{array}{l}\text { Siswa dapat menuliskan solusi } \\
\text { matematika }\end{array}$ & $\begin{array}{l}\text { Siswa dapat menemukan solusi dengan cara } \\
\text { membuat pohon faktor untuk menentukan } \\
\text { faktor prima dari } N \text { yang sudah diketahui }\end{array}$ \\
\hline 5 & $\begin{array}{l}\text { Siswa dapat menuliskan kesimpulan } \\
\text { jawaban }\end{array}$ & $\begin{array}{l}\text { Siswa dapat menyimpulkan bahwa faktor } \\
\text { prima merupakan bilangan prima yang } \\
\text { mempunyai faktor sebanyak dua, sedangkan } \\
\text { yang bukan faktor prima merupakan bilangan } \\
\text { komposit yang mempunyai faktor lebih dari } \\
\text { dua, yang faktornya dapat dicari dengan } \\
\text { menggunakan pohon faktor }\end{array}$ \\
\hline
\end{tabular}

Sedangkan hasil lembar jawaban siswa yang tidak mampu berkomunikasi secara tertertulis dalam menyelesaikan faktor prima dapat dilihat pada Gambar 2.

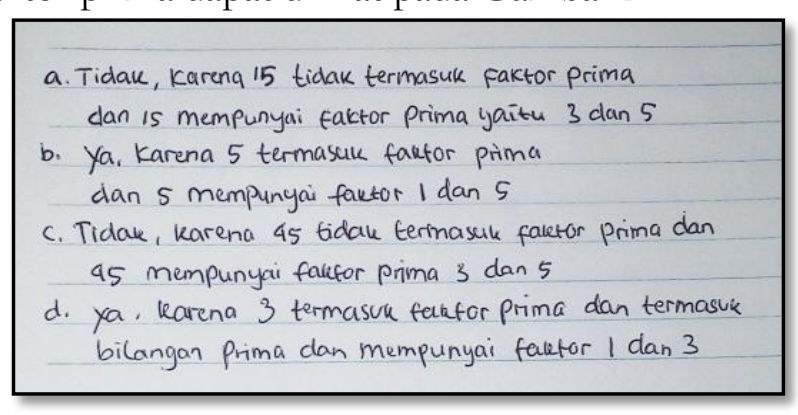

Gambar 2. Siswa yang tidak mampu berkomunikasi secara tertulis

Dari Gambar 2 di atas peneliti mendeskripsikan jawaban siswa yang tidak mampu dalam berkomunikasi secara tertulis dalam menyelesaikan faktor prima sesuai dengan indikator komunikasi secara tertulis dapat dilihat pada Tabel 2 dibawah ini.

Tabe1 2. Deskripsi jawaban siswa yang tidak mampu berkomunikasi secara tertulis

\begin{tabular}{|c|c|c|}
\hline No & Indikator komunikasi secara tertulis & Deskripsi jawaban siswa \\
\hline 1 & $\begin{array}{l}\text { Siswa dapat menuliskan konsep } \\
\text { kedalam bahasa matematika }\end{array}$ & - \\
\hline 2 & $\begin{array}{l}\text { Siswa dapat menuliskan masalah } \\
\text { kedalam bahasa matematika }\end{array}$ & $\begin{array}{l}\text { Siswa mampu menjelaskan bahwa bilangan } 15 \\
\text { dan } 45 \text { bukan merupakan faktor prima yang } \\
\text { memiliki lebih dari dua faktor, sedangkan } \\
\text { bilangan } 5 \text { dan } 3 \text { adalah bilangan prima yang } \\
\text { mempunyai dua faktor. } 5 \text { memiliki faktor } \\
\text { yaitu } 1 \text { dan } 5 \text { sedangkan } 3 \text { memiliki faktor } \\
\text { yaitu } 1 \text { dan } 3 \text {. }\end{array}$ \\
\hline 3 & $\begin{array}{l}\text { Siswa dapat menuliskan } \\
\text { perhitungan }\end{array}$ & - \\
\hline 4 & $\begin{array}{l}\text { Siswa dapat menuliskan solusi } \\
\text { matematika }\end{array}$ & - \\
\hline 5 & $\begin{array}{l}\text { Siswa dapat menuliskan kesimpulan } \\
\text { jawaban }\end{array}$ & - \\
\hline
\end{tabular}


Sedangkan hasil jawaban siswa per item dalam bentuk komunikasi siswa secara tertulis yang digunakan siswa dalam menyelesaikan faktor prima dapat dilihat pada Tabel 3.

Tabe1 3. Hasil jawaban siswa per item

\begin{tabular}{|c|c|c|c|c|c|}
\hline \multirow{2}{*}{ Pertanyaan } & \multirow{2}{*}{ Nomor 1} & \multirow{2}{*}{$\begin{array}{c}\text { Pertanyaan } \\
\text { Jika } N=3 \times 5 \times 9\end{array}$} & \multicolumn{2}{|c|}{ Menjawab } & \multirow{2}{*}{$\begin{array}{c}\text { Tidak } \\
\text { menjawab }\end{array}$} \\
\hline & & & Ya & Tidak & \\
\hline \multirow{4}{*}{ Penjelasan } & (a) & $\begin{array}{l}\text { Apakah } 15 \text { merupakan faktor prima } \\
\text { dari } N\end{array}$ & 13 & 27 & 6 \\
\hline & (b) & $\begin{array}{l}\text { Apakah } 5 \text { merupakan faktor prima } \\
\text { dari } N\end{array}$ & 35 & 5 & 6 \\
\hline & (c) & $\begin{array}{l}\text { Apakah } 45 \text { merupakan faktor prima } \\
\text { dari } N\end{array}$ & 14 & 26 & 6 \\
\hline & (d) & $\begin{array}{l}\text { Apakah } 3 \text { merupakan faktor prima } \\
\text { dari } N\end{array}$ & 33 & 7 & 6 \\
\hline
\end{tabular}

Pada Tabel 3, subjek dalam penelitian berjumlah 46 siswa, pada soal 1(a) siswa yang mampu menjawab benar sebanyak 27, dengan memilih jawaban "Tidak". Sedangkan yang menjawab salah sebanyak 13, dengan memilih jawaban "Ya". tidak menjawab sama sekali berjumlah 6 siswa. pada soal 1(b) siswa yang mampu menjawab dengan benar berjumlah 35, dengan pilihan jawaban "Ya". Sedangkan yang menjawab salah berjumlah 5, dengan pilihan jawaban "Tidak". dan yang tidak menjawab sama sekali berjumlah 6 siswa. Pada soal 1(c) siswa yang mampu menjawab dengan benar berjumlah 26, dengan pilihan jawaban "Tidak". Sedangkan yang menjawab salah berjumlah 14, dengan pilihan jawaban "Ya". Dan yang tidak menjawab sama sekali berjumlah 6 siswa. Pada soal 1(d) siswa yang mampu menjawab dengan benar berjumlah 33, dengan pilihan jawaban "Ya". Sedangkan yang menjawab salah berjumlah 7, dengan pilihan jawaban "Tidak". Siswa yang tidak menjawab sama sekali sebanyak 6 .

Berdasakan hasil jawaban pada Tabel 3 diatas, rata-rata siswa dapat memberikan jawaban dengan benar dan mampu berkomunikasi secara tertulis. Namun penelitian ini bukan bertujuan untuk mengetahui komunikasi siswa secara tertulis saja dalam menyelesaikan faktor prima, tetapi juga mengidentifikasi komunikasi siswa secara lisan yang mereka gunakan dalam menyelesaikan faktor prima dalam bentuk wawancara. Berikut ini adalah hasil transkip wawancara peneliti dengan subjek dalam kategori siswa yang mampu berkomunikasi secara tertulis.

$P$ : berapakah nilai dari $\mathrm{N}$ ?

$S$ : nilai $\mathrm{N}$ yaitu 135 .

$P$ : bagaimana kamu mengetahui nilai $\mathrm{N}$ yaitu 135 ?

$S: N=3 \times 5 \times 9$ maka $3 \times 5 \times 9=135$

$P$ : apakah bilangan $15,5,45$ dan 3 termasuk faktor prima dari $\mathrm{N}$ ?

$S$ : dari bilangan 15, 5, 45 dan 3 , terdapat dua yang merupakan faktor prima dan dua yang tidak termasuk faktor prima dari $\mathrm{N}$.

$P$ : bilangan apa saja yang termasuk faktor dari $\mathrm{N}$ ?

$S$ : bilangan 5 dan 3 termasuk faktor prima dari $N$ sedangkan 15 dan 45 bukan faktor prima dari $N$.

$P$ : mengapa bilangan 5 dan 3 termasuk faktor prima sedangkan 15 dan 45 bukan faktor prima?

$S$ : karena 5 dan 3 termasuk bilangan prima, sedangkan 15 dan 45 bukan bilangan prima. $\mathrm{N}=135$ jika diselesaikan dengan menggunakan pohon faktor hanya bilangan 5 dan 3 termasuk faktor primanya 15 dan 45 bukan faktor prima dari 135

$P$ : apakah kamu yakin dengan jawabanmu?

$S$ : ya, saya yakin 
Representasi verbal siswa sekolah menengah pertama dalam...

Berikut ini adalah hasil transkip wawancara peneliti dengan subjek dalam kategori siswa yang tidak mampu berkomunikasi secara lisan.

$P$ : apakah semua soal 1 (a), (b), (c), dan (d) merupakan faktor prima dari N?

$S$ : tidak, karena hanya ada dua soal yang merupakan faktor prima dan dua soal yang tidak termasuk faktor prima dari $\mathrm{N}$.

$P$ : Soal nomor berapakah itu?

$S$ : pada soal 1(b) dan 1(d).

$P$ : mengapa hanya soal 1 (b) dan 1 (d) merupakan faktor prima dari $\mathrm{N}$ ?

$S$ : karena bilangan 5 dan 3 memiliki dua faktor, faktor prima dari 5 yaitu 1 dan 5 , faktor prima dari 3 yaitu 1 dan 3, dan sekaligus bilangan 5 dan 3 termasuk bilangan prima.

$P$ : dari penjelasan kamu tadi ternyata kamu mampu menjelaskan bahwa 5 dan 3 merupakan faktor prima, tetapi mengapa dalam lembar kerja tidak kamu jelaskan?

$S$ : saya mengalami kesulitan dalam menulis kalimat dari faktor prima.

Berdasarkan hasil transkip wawancara diatas, dapat disimpulkan bahwa siswa yang mampu berkomunikasi secara tertulis juga mampu berkomunikasi secara lisan, karena; 1) dapat menjelaskan bilangan prima dan komposit; 2) mampu memecahkan faktor prima kedalam bahasa matematika; 3) menjelaskan operasi hitung pada faktorisasi prima yang diperoleh dengan cara pohon faktor; 4) menemukan solusi dalam menyelesaikan faktor prima; 5) menjelaskan interpretasi jawaban faktor prima melalui ide-ide atau pendapatnya. Siswa yang tidak mampu berkomunikasi secara tertulis diperoleh data bahwa siswa juga mampu berkomunikasi secara lisan, dibuktikan siswa mampu menjelaskan tentang faktor prima.

Baroody (1993), berpendapat bahwa komunikasi matematis terbagi menjadi dua yaitu secara tertulis dan secara lisan. Tes diberikan kepada 46 siswa yang digunakan untuk mengidentifikasi komunikasi siswa secara tertulis dalam menyelesaikan faktor prima, diperoleh hasil berjumlah 40 siswa yang mampu berkomuniaksi secara tertulis dengan prosentase $87 \%$, sedangkan berjumlah 6 siswa yang tidak mampu berkomunikasi secara tertulis dengan prosentase $13 \%$. kemudian dilakukan wawancara untuk mengidentifikasi komunikasi siswa secara lisan dalam menyelesaikan faktor prima. Hasil dari wawancara diperoleh hasil bahwa siswa mampu berkomunikasi secara tertulis juga mampu berkomunikasi secara lisan, sedangkan siswa yang tidak mampu berkomunikasi secara tertulis, ternyata siswa juga mampu berkomunikasi secara lisan. Hal tersebut juga sejalan dengan pendapat Solso, Maclin, \& Maclin (2008) menjelaskan bahwa kemampuan verbal seseorang diperoleh dari otak kiri, sehingga dapat mendeskripsikan sesuatu dari hasil visualnya. Sedangkan komunikasi tidak terbatas hanya pada satu bentuk, sehingga dapat terwujud dalam berbagai bentuk komunikasi lainnya. Siswa lebih efesien dalam mengomunikasikan secara lisan dan tertertulis dengan mudah dalam menafsirkan ide tersebut melalui pohon faktor (Zazkis \& Liljedahl, 2004). Komunikasi matematis berupa lisan dan tertulis yang digunakan oleh siswa dalam menyelesaikan faktor prima sama halnya dengan representasi verbal, karena representasi verbal yaitu berupa kata-kata, lisan dan deskripsi (AduGyamfi, 2003; Prain \& Waldrip, 2006; As'ari, 2009; Kohnle \& Passante, 2017).

Jumlah 6 siswa yang tidak mampu berkomunikasi secara tertulis dalam menyelesaikan faktor siswa, dipengaruhi salah satunya yaitu guru kurang memberikan sebuah konsep pemahaman kepada siswa tentang faktor prima. Sejalan dengan hasil tersebut Zazkis \& Gaodwsky (2001) menyatakan bahwa guru kurang memberikan pemahaman tentang sebuah konsep bahwa " $B$ adalah faktor $A$ " dan sama halnya dengan " $A$ habis dibagi oleh $B$ ". Dalam penelitiannya memberikan sebuah contoh penyelesaian tentang faktor prima dari bilangan 117 , jika $117=33 \times 132$ dan meminta siswa untuk menjelaskan semua faktor yang habis dibagi oleh bilangan tersebut. Siswa berusaha memfaktorkan 117 dengan cara menggunakan pohon faktor, agar lebih mudah menentukan faktor dari 117. Dengan cara tersebut komunikasi siswa sangat penting dalam matematika karena sebagai alat untuk berpikir dan mengaitkan pengetahuan 
sebelumnya dalam menyelesaikan masalah matematika (Diezmann, 2001). Siswa yang mampu berkomunikasi secara lisan, dapat diartikan bentuk deskripsi menghubungkan antara objek dengan simbol matematika (Hwang, 2007).

Dari hasil penelitian terlihat bahwa rata-rata siswa mampu mengomunikasikan secara tertulis dalam bentuk pohon faktor, karena siswa hanya mempunyai pengalaman menyelesaikan faktor prima dengan menggunakan pohon faktor sesuai dengan pengalaman yang diperolehnya ketika belajar di sekolah dasar. Hal tersebut penulis juga memperoleh informasi dari guru yang saat ini siswanya sedang duduk dikelas VII SMP yang dijadikan penulis sebagai subjek penelitian, bahwa dalam menyelesaikan faktor prima metode yang digunakan adalah dengan menggunakan pohon faktor. Namun dibuku Matematika SMP kelas VII K-13 dalam menentukan faktor prima selain dengan cara menggunakan pohon faktor juga menggunakan pembagian bersusun, namun siswa lebih cenderung senang dengan menggunakan pohon faktor, karena pohon faktor dianggap paling sederhana dan sudah terbiasa digunakan sejak di sekolah dasar.

\section{KESIMPULAN}

Komunikasi yang digunakan siswa dalam menyelesaikan faktor prima dengan menggunakan komunikasi secara tertulis dan lisan. Dari hasil analisis jawaban siswa dan Dari hasil analisis lembar kerja siswa dan transkip wawancara, dapat diketahui siswa mampu berkomunikasi secara tertulis dalam menyelesaikan faktor prima dengan cara menggunakan pohon faktor sebagai alternatif untuk mencari solusi dalam menyelesaikan faktor prima, dan siswa mampu mengomunikasikan faktor prima melalui komunikasi secara lisan yang dibuktikan dengan transkip wawancara yang hasilnya telah memenuhi enam indikator komunikasi secara lisan.

\section{DAFTAR PUSTAKA}

Adu-Gyamfi, K. (2003). External multiple representations in mathematics teaching. North Carolina State University.

Arcavi, A. (2003). The role of visual representations in the learning of mathematics. Educational Studies in Mathematics, 52(3), 215-241.

As'ari, A. R. (2009). Representasi: Pentingnya dalam Pembelajaran Matematika. Jurnal Matematika, 7(2), 81-91.

Baroody. A. J (1993). Problem Solving, Reasoning, and Comunnicating, K-8 Helping Children Think Mathematically. New York: Macmillan Publishsing Company.

Bartell, T. G., Webel, C., Bowen, B., \& Dyson, N. (2013). Prospective teacher learning: recognizing evidence of conceptual understanding. Journal of Mathematics Teacher Education, 16, 57-79. https://doi.org/10.1007/s10857-012-9205-4

Boonen, J. H. A., Wesel, F. V., Jolles, J., \& Schoot, M. V. D. (2014). The Role of Visual Representation Type, Spatial Ability, and Reading Comprehension in Word Problem Solving: An Item-Level Analysis in Elementary School Children. International Journal of Educational Research, 68, 15-26. https://doi.org/10.1016/j.ijer.2014.08.001

Burkhart, J. (2009). Building numbers from primes. Mathematics Teaching in the Middle School, 15(3), 156-167.

ÇELIK, D., \& Arslan, A. S. (2012).The Analysis of Teacher Candidates' Translating Skills in Multiple Representations. Elementary Education Online, 11(1), 239-250.

Cooney, T. J. (1999). Conceptualizing teachers' ways of knowing. Educational Studies in Mathematics, 38, 163-187. https://doi.org/10.1023/A:1003504816467

Cresswell, J. W. (2009). Research Design: Qualitative, quantitative, and mixed methods approaches. London: SAGE Publications Ltd.

Diezmann, C., \& English, L., (2001). Promoting the use of diagrams as tools for thinking. In A. Cuoco (Ed.), The roles of representation in school mathematics. 2001 Yearbook of the National 
Representasi verbal siswa sekolah menengah pertama dalam...

Council of Teachers of Mathematics (pp. 77-89). Reston, VA: National Council of Teachers of Mathematics.

Dündar, S. (2015). Mathematics Teacher-Candidates Performance in Solving Problem with Different Representation Style: The Trigonometry Example. Eurasia Journal of Mathematics, Science \& Technology Education, 11(6), 1379-1397. https://doi.org/10.12973/eurasia.2015.1396a

Hoogland, K., de Koning, J., Bakker, A., Pepin, B. E. U., \& Gravemeijer, K. (2018). Changing representation in contextual mathematical problems from descriptive to depictive: The effect on students' performance. Studies in Educational Evaluation, 58(April), 122-131. https://doi.org/10.1016/j.stueduc.2018.06.004

Hussien, A. M. (2018). Culture of Traits in Arabic Language Education: Students' Perception of the Communicative Traits Model. International Journal of Instruction, 11(4), 467-484. https://doi.org/10.12973/iji.2018.11429

Hwang, W.-Y., Chen, N.-S., Dung, J.-J., \& Yang, Y.-L. (2007). Multiple Representation Skills and Creativity Effects on Mathematical Problem Solving using a Multimedia Whiteboard System. Educational Technology \& Society, 10(2), 191-212.

Jordan, R. F., (2016). Strengthen Elementary Students' Understanding Of Factors. Undergraduate Theses and Professional Papers. 25. https://scholarworks.umt.edu/utpp/25.

Kemendikbud. (2013). Permendikbud No.81 A tentang Implementasi Kurikulum Lampiran 10. Jakarta: Departemen Pendidikan dan Kebudayaan.

Kohnle, A., \& Passante, G. (2017). Characterizing representational learning: A combined simulation and tutorial on perturbation theory. Physical Review Physics Education Research, 13(2), 020131. DOI: 10.1103/PhysRevPhysEducRes.13.020131.

Murat, G., \& Funda, Y. H. (2016). Modal Representations and their Role in the Learning Process: A Theoretical and Pragmatic Analysis. Educational Sciences: Theory \& Practice, 16(1).109-126. DOI 10.12738/estp.2016.1.0054.

NCTM. (2000). Principles and Standards for School Mathematics. United States of America: The National Council of Teachers of Mathematics, Inc.

Ningsih, S. K., Narahara, S., \& Mulyono, H. (2018). An Exploration of Factors Contributing to Students' Unwillingness to Communicate in a Foreign Language across Indonesian Secondary Schools. International Journal of Instruction, 11(4), 811-824. https://doi.org/10.12973/iji.2018.11451

Prain, V., \& Waldrip, B. (2006). An exploratory study of teachers' and students' use of multimodal representations of concepts in primary science. International Journal of Science Education, 28, 1843-1866.

Rahmad, B. A., \& Dwi, R. (2017). Symbolic and Verbal Representation Process of Student in Solving Mathematics Problem Based Polya's Stages. Journal International Education Studies, 10(10), 20-28. https://doi.org/10.5539/ies.v10n10p20

Reynolds, J. A., Thaiss, C., Katkin, W., Robert, J., \& Thompson, J. (2012). Writing-to-learn in undergraduate science education: A community-based, conceptually driven approach. CBE Life Sciences Education, 11(1), 17-25.

Rogers, E. M., \& Rekha A. R. (1976). Communication In Organization. New York: The Free Press.

Roscoe, M. \& Feldman Z. (2015). Strengthening prospective elementary teachers' understanding of factors. In Che, S. M. and Adolphson, K. A. (Eds.). Proceedings for the $42 n d$ Annual Meeting of the Research Council on Mathematics Learning. Las Vegas, NV.

Saavedra, A. R., \& Opfer, V. D. (2012). Teaching and learning $21^{\text {st }}$ century skills: Lessons from the learning sciences. London: RAND Corporation.

Severin, W. J. (2005). Teori komunikasi: Sejarah, metode, dan terapan di dalam media massa. Jakarta: Kencana.

Shannon, C. E., \& Weaver, W. (1949). The Mathematical Theory of Communication. Urbana, IL: University of Illinois Press. 
Solso, R. L., Maclin, O. H., \& Maclin, M. K. (2008). Psikologi Kognitif. Jakarta: Erlangga.

Sugiyono. (2012). Memahami Penelitian Kualitatif. Bandung: Alfabeta.

Sukiyanto, S. (2020). Munculnya Kesadaran Metakognisi Dalam Menyelesaikan Masalah Matematika. Aksioma: Jurnal Program Studi Pendidikan Matematika, 9(1), 126-132.

Utami, A. D., Sa'dijah, C., Subanji, \& Irawati, S.. (2019). Students' Pre-Initial Mental Model: The Case of Indonesian First-Year of College Students. International Journal of Instruction, 12(1), 1173-1188. https://doi.org/10.29333/iji.2019.12175a

van de Walle, J. A., Karp, K. S., \& Bay-Williams, J. M. (2008). Elementary and middle school mathematics, teaching developmentally. USA: Pearson.

Wagner, T. (2008). The global achievement gap: Why even our best schools don't teach the new survival skills our children need-and what we can do about it. New York, NY: Basic Books.

Wildan, W., Hakim, A., Siahaan, J., \& Anwar, Y. A. S. (2019). A Stepwise Inquiry Approach to Improving Communication Skills and Scientific Attitudes on a Biochemistry Course. International Journal of Instruction, 12(4), 407-422. https://doi.org/10.29333/iji.2019.12427a

Yaniawati, R. P., Kartasasmita, B. G, Kariadinata, R., \& Sari, E. (2017). Accelerated learning method using Edmodo to increase students' mathematical connection and selfregulated learning. In Proceedings of the 2017 International Conference on Education and Multimedia (pp. 5357). Singapore: ACM.

Zazkis, R., \& Gadowsky, K. (2001). Attending to transparent features of opaque representations of natural numbers. In A. A. Cuoco \& F. R. Curcio (Eds.), Roles of representation in school mathematics: 2001 yearbook (pp. 44-52). Reston, VA: NCTM.

Zazkis, R., \& Liljedahl, P. (2004). Understanding Primes: The Role of Representation. Journal for Research in Mathematics Education, 35(3), 164-186. 